\title{
KARAKTERISASI NANOPARTIKEL EKSTRAK ETANOL KAYU MANIS (Cinnamomum burmanii) DENGAN KITOSAN SODIUM TRIPOLIFOSFAT SEBAGAI KANDIDAT ANTIOKSIDAN
}

\author{
Irma Antasionasti ${ }^{1 *}$, Imam Jayanto ${ }^{1}$, Surya Sumantri Abdullah ${ }^{1}$, Jainer Pasca Siampa ${ }^{1}$ \\ ${ }^{1}$ Program Studi Farmasi, Fakultas Matematika dan Ilmu Pengetahuan Alam Universitas Sam Ratulangi, \\ Jl. Kampus Unsrat, Kleak, Manado 95115 Sulawesi Utara
}

\begin{abstract}
ABSTRAK
Ekstrak etanol kayu manis memiliki kandungan fenol yang tinggi yang berpotensi sebagai antioksidan tetapi memiliki bioavailabilitas yang rendah pada kondisi ukuran partikel yang besar. Oleh karena itu, dilakukan analisis karakteristik nanopartikel ekstrak etanol kayu manis. Tujuan penelitian untuk membuat dan mengevaluasi karakteristik nanopartikel ekstrak kayu manis sebagai kandidat antioksidan secara in vitro. Preparasi nanopartikel ekstrak etanol kayu manis dengan metode gelasi ionik. Nanopartikel ekstrak etanol kayu manis memiliki ukuran partikel sebesar 400,3 nm dengan potential zeta $+6,60 \mathrm{mV}$. Spektra Fourier Transform Infrared (FTIR) menunjukkan adanya gugus hidroksil dan gugus amida dari kitosan dan gugus fosfat dari STPP. Studi aktivitas antioksidan secara in vitro dengan metode 2,2-diphenyl-1-picrylhydrazyl (DPPH), 2,2'-azino-bis (3ethylbenzothiazoline-6-sulfonic acid (ABTS) dan reduksi besi III menunjukkan bahwa nanopartikel ekstrak etanol kayu manis memiliki aktivitas antioksidan yang lebih kecil dibandingkan ekstrak tetapi masih dalam kategori sangat kuat. Aktivitas antioksidan yang diberikan dipengaruhi oleh kandungan total fenolik dan total flavonoid secara berturut-turut sebesar 75,685 \pm 1,408 \% EAG dan 60,546 \pm 0,670 \% EK untuk ekstrak etanol kayu manis serta $61,845 \pm 0,529 \%$ EAG dan 57,939 \pm 0,446 \% EK untuk nanopartikel ekstrak etanol kayu manis. Penerapan teknologi nanopartikel pada ekstrak etanol kayu manis melalui ikat silang antara kitosan-TPP dapat mempertahankan aktivitas antioksidannya.
\end{abstract}

Kata kunci: antioksidan, kayu manis, nanopartikel.

\section{ABSTRACT}

Ethanol extract of cinnamon has a high phenol content which is potential as an antioxidant but has a low bioavailability under conditions of large particle size. Therefore, nanoparticles were prepared for the ethanol extract of cinnamon. The aim of this research was to make and evaluate the characteristics of cinnamon nanoparticles as antioxidant candidates in vitro. The cinnamon nanoparticles were prepared using the ionic gelation method. Cinnamon nanoparticles has a particle size of $400,3 \mathrm{~nm}$ with a zeta potential of $+6,60 \mathrm{mV}$. Fourier Transform Infrared (FTIR) spectra showed the presence of a hydroxyl and amida group from chitosan and a phosphate group from STPP. In vitro antioxidant activity studies with the 2,2-diphenyl-1-picrylhydrazyl (DPPH), 2,2'-azino-bis (3-ethylbenzothiazoline-6-sulfonic acid (ABTS) method and ferric reducing activity power showed that cinnamon nanoparticle has smaller antioxidant activity than the extract but is still in the very strong category. The antioxidant activity given is influenced by the total phenolic and total flavonoids content $75.685 \pm$ $1.408 \%$ EAG and $60.546 \pm 0.670 \%$ EK for cinnamon ethanol extract. and $61.845 \pm 0.529 \%$ EAG and $57.939 \pm$ $0.446 \%$ EK for cinnamon ethanol extract nanoparticles, respectively The application of nanoparticle technology to the ethanol extract of cinnamon through chitosan-TPP cross-linking can maintain its antioxidant activity.

Keywords: antioxidant, cinnamon, nanoparticle

\section{PENDAHULUAN}

Kayu manis (Cinnamomum burmanii) merupakan salah satu dari 250 spesies cinnamomum dan bagian yang dimanfaatkan umumnya berupa kulit batang. Kulit batang kayu manis mengandung karbohidrat 59,55\%; protein $4,65 \%$; lemak $2,2 \%$; serat $20,3 \%$; abu $3,55 \%$ dan air 9,9\%. Dibidang industri kayu manis dimanfaatkan sebagai flavoring agent dan

\footnotetext{
Korespondensi:

Telepon: -

Email: irmaantasionasti07@gmail.com

DOI: https://doi.org/10.35799/cp.13.2.2020.31392
}

pewarna dan dibidang kesehatan dimanfaatkan sebagai obat tradisional karena memiliki sifat antioksidan, antimikroba dan antidiabetes (Ervina dkk., 2016; Abdelwahab dkk., 2017; Nawasari, 2018; Shahid dkk., 2019; Ervina dkk., 2019; Sana dkk., 2019; dan Muhammad dkk.,2020).

Wijayanti dkk. (2011) melaporkan bahwa ekstrak etanol kulit kayu manis Indonesia yang dikumpulkan dari berbagai daerah memiliki 
aktivitas antioksidan dengan nilai $\mathrm{IC}_{50}$ dalam kisaran 75,48 $\mu \mathrm{g} / \mathrm{mL}$ dan 136,88 $\mu \mathrm{g} / \mathrm{mL}$ Aktivitas antioksidan kayu manis dipengaruhi oleh senyawa metabolit sekundernya, seperti katekin, epikatekin, procyanidin B2, kuersetin, 3,4-dihidroksibenzaldehida, dan sinamaledhid (Muhammad dkk., 2020). Senyawa sinamaldehid merupakan agen antioksidan kuat yang secara efektif dapat meredam radikal bebas seperti anion superoksida dan radikal hidroksil, serta radikal bebas lainnya dalam pengujian in vitro (Ariestiani dkk., 2018). Senyawa sinamaldehid yang termasuk dalam golongan fenilpropanoid merupakan turunan senyawa fenol. Bahan aktif alami yang tergolong turunan senyawa polifenol memiliki bioavailabilitas yang rendah pada kondisi ukuran partikel yang besar sehingga sulit untuk menembus membran lipid dari sel tubuh (Munin dan Edwards-lévy, 2011), tidak stabil terhadap pengaruh suhu dan intesitas cahaya tinggi sehingga mudah teroksidasi.

Salah satu strategi potensial yang dapat diaplikasikan adalah dengan memformulasikannya dengan suatu polimer menjadi sediaan nanopartikel yang bersifat lebih mudah terdispersi stabil dalam air (Saha dkk., 2010) sebagai upaya pengembangan saintifikasi herbal kayu manis melalui pengujian antioksidan secara in vitro. Gelasi ionik adalah salah satu metode yang paling mudah diimplementasikan dalam memproduksi delivery system berbasis polimer (Fathi dan Julian, 2014). Ekstrak etanol kayu manis dapat bermuatan negatif dalam air karena adanya gugus hidroksil dari senyawa polifenol dapat mengadakan interaksi ionik dengan gugus-gugus bermuatan positif dari gugus amin kitosan. Penggunaan kitosan sebagai bahan nanopolimer perlu penambahan STTP sebagai cross-linking agent untuk menstabikan polimer nanopartikel (Mora-huertas dkk., 2010).

Berdasarkan latar belakang diatas, peneliti tertarik untuk melakukan penelitian tentang preparasi nanopartikel ekstrak etanol kayu manis menggunakan polimer kitosan. Selanjutnya, dilakukan karakterisasi nanopartikel dan menguji aktivitas biologis sebagai kandidat antioksidan secara in vitro.

\section{BAHAN DAN METODE}

\section{Bahan dan alat}

Bahan-bahan yang digunakan yaitu kayu manis yang diperoleh dari Desa Kawangkoan,
Kabupaten Minahasa, Sulawesi Utara, senyawa 2,2-diphenyl-1-picrylhidrazil (DPPH) (Sigma), senyawa 2,2'-azino-bis(3-ethylbenzthiazoline-6sulfonic acid) (ABTS) (Sigma), reagen FolinCiocalteu (Merck), potassium persulfate (Merck), natrium karbonat (Merck), natrium hidroksida (Merck), aluminium klorida (Merck), natrium nitrit (Merck), bufer fosfat $0,2 \mathrm{M} \mathrm{(pH}$ 6,6) (Merck), kalium ferisianida (Merck), besi(III) klorida (Merck), vitamin C (Merck), asam triklorasetat (TCA) (Merck), etanol 96\% (Merck), etanol (p.a) (Merck), akuades (Merck), asam galat (Sigma), kuersetin (Sigma), asam asetat (Merck), natrium asetat (Merck), STPP (Merck), dan Kitosan (p,a) (Sigma). Peralatan yang digunakan yaitu seperangkat alat maserasi, neraca analitik dengan kepekaan $0,1 \mathrm{mg}$ (Mettler Toledo), Vacuum rotary evaporator (Heidolph VV 2000), spektrofotometer UV-VIS (Genesys5), analisator ukuran partikel dan potensial zeta (Zetasizer Ver. 7. 01 Serial Number MAL1061025) dan alat-alat gelas yang lazim digunakan di Laboratorium Kimia Analisis.

\section{Pembuatan ekstrak etanol kayu manis}

Serbuk kayu manis diekstraksi dengan menggunakan metode maserasi menggunakan pelarut etanol 96\%. Proses maserasi dilakukan selama 3 hari dan dilakukan remaserasi sebanyak 2 kali ditandai dengan hilangnya warna maserat dan dengan pengadukan. Filtrat yang diperoleh kemudian diuapkan menggunakan vacuum rotary evaporator pada suhu $60^{\circ} \mathrm{C}$ dan diperoleh ekstrak kental etanol.

\section{Preparasi nanopartikel ekstrak etanol kayu manis}

Proses enkapslasi dilakukan berdasarkan penelitian Adhyatmika dkk., (2017) dengan cara membuat $500 \mathrm{~mL}$ larutan ekstrak etanol $0,1 \%$ dalam pelarut etanol dan kitosan $0,4 \%$. Keduanya dicampurkan dalam gelas beaker ukuran satu liter dengan pengadukan menggunakan pengadukan magnetic dengan kecepatan $1.500 \mathrm{rpm}$ selama 20 menit. Selanjutnya ditambahkan STPP $0,1 \%$, dan pengadukan dilanjutkan kembali selama 20 menit. Sampai terbentuk suspense nanopartikel. Setelah itu, menganalisis nanopartikel yang terbentuk menggunakan Particle Size Analyzer (PSA), Potensial zeta dan FTIR untuk mengetahui karakteristik nano enkapsulan. 
Uji aktivitas antioksidan ekstrak dan nanoepartikel ekstrak etanol kayu manis

a. Penentuan aktivitas penangkapan radikal $\mathrm{DPPH}$

Aktivitas penangkapan radikal DPPH dilakukan sebagaimana dalam Kikuzaki dkk. (2002) dengan cara berikut: sebanyak $50 \mu \mathrm{L}$ sampel uji dengan berbagai konsentrasi (Konsentrasi yang memberikan nilai $\mathrm{IC}_{50}$ yakni konsentrasi fraksi yang memberikan persen aktivitas penangkapan radikal sebesar $50 \%$ dibanding kontrol melalui suatu persamaan garis regresi linier), ditambah dengan 1,0 $\mathrm{mL}$ DPPH $0,4 \mathrm{mM}$, dan 3,950 $\mathrm{mL}$ etanol. Campuran selanjutnya divorteks dan dibiarkan selama 30 menit. Larutan selanjutnya diukur absorbansinya pada panjang gelombang $517 \mathrm{~nm}$ terhadap blanko (yang terdiri atas $50 \mu \mathrm{L}$ ekstrak dan $4,950 \mathrm{~mL}$ etanol). Dilakukan juga pengukuran absorbansi kontrol yang terdiri atas $1,0 \mathrm{~mL}$ DPPH dan 4,0 mL etanol. Sebagai pembanding digunakan Vitamin $\mathrm{C}$ yang keduanya sudah diketahui sebagai antioksidan sebagaimana dilakukan oleh (Kikuzaki dkk., 2002).

Persen (\%) penangkapan radikal $=\left(\mathrm{A}_{\mathrm{o}}-\mathrm{A}_{1} / \mathrm{A}_{\mathrm{o}}\right) \times 100 \%$

Ket: $\mathrm{A}_{\mathrm{o}}$ adalah absorbansi kontrol (tidak mengandung sampel uji) dan $A_{1}$ merupakan absorban dengan adanya sampel uji atau senyawa pembanding.

b. Penentuan aktivitas penangkapan radikal ABTS

Penentuan aktivitas penangkapan radikal ABTS mengikuti metode Re et al. (1999) cit Aktumsek et al. (2013). Radikal kation ABTS $\left(\right.$ ABTS $^{+}$) diproduksi melalui reaksi 7 $\mathrm{mM}$ larutan ABTS dengan 2,45 mM potassium persulfat. Larutan tersebut disimpan 12-16 jam dalam ruangan gelap dan suhu kamar. Sebelum dilakukan pengujian, larutan diencerkan dengan etanol untuk mendapatkan absorbansi $0,800 \pm 0,02$ pada panjang gelombang $750 \mathrm{~nm}$. Sebanyak $4 \mathrm{~mL}$ ekstrak etanol ditambahkan dengan $1 \mathrm{~mL}$ larutan ABTS dan dicampur. Campuaran dibiarkan pada suhu kamar selama 30 menit dan absorbansi diukur pada panjang gelombang $750 \mathrm{~nm}$. Hasilnya dilaporkan menggunakan persentasi inhibisi dan perhitungannya berdasarkan :

Persen $(\%)$ penangkapan radikal $=\left(\mathrm{A}_{\mathrm{o}}-\right.$ $\left.\mathrm{A}_{1} / \mathrm{A}_{\mathrm{o}}\right) \times 100 \%$

Ket: $\mathrm{A}_{\mathrm{o}}$ adalah absorbansi kontrol (tidak mengandung sampel uji) dan $A_{1}$ adalah absorbansi dengan adanya sampel uji atau senyawa pembanding (vitamin c). c. Uji daya mereduksi besi (III) menjadi besi (II)

Penentuan aktivitas mereduksi besi (III) menjadi besi (II) dilakukan sebagaimana Hinneburg dkk. (2006). Sebanyak 1,0 mL alikuot sampel uji yang dilarutkan dalam air dicampur dengan 2,5 mL buffer fosfat $0,2 \mathrm{M}$ (pH 6,6) dan 2,5 mL kalium ferisianida $1 \%$ lalu diinkubasi pada suhu $50^{\circ} \mathrm{C}$ selama 30 menit. Setelah selesai inkubasi, campuran ditambah dengan $2,5 \mathrm{~mL}$ asam trikloroasetat $10 \%$ untuk menghentikan reaksi. Campuran selanjutnya disentrifus pada kecepatan 3000 rpm selama 10 menit. Sebanyak 2,5 mL supernatan (lapisan atas) selanjutnya dicampur dengan $2,5 \mathrm{~mL}$ air dan $0,5 \mathrm{~mL}$ besi(III) klorida $0,1 \%$ dan absorbansinya diukur pada panjang gelombang $700 \mathrm{~nm}$.

d. Penentuan kandungan fenolik total

Kandungan fenolik total ditentukan dengan metode spektrofotometri seperti yang dilakukan oleh Chun dkk. (2003) dengan cara: sejumlah tertentu sampel dimasukkan ke dalam labu takar $10 \mathrm{ml}$, ditambah dengan $0,4 \mathrm{ml}$ reagen Folin-Ciocalteu, dan dibiarkan selama 58 menit. Selanjutnya larutan ini ditambah dengan $\mathrm{Na}_{2} \mathrm{CO}_{3} \quad 7 \%$ sebanyak $4 \mathrm{ml}$ dan ditambah aqua bidestilata sampai batas tanda. Setelah 2 jam, absorbansinya dibaca pada panjang gelombang $755 \mathrm{~nm}$ terhadap blanko yang terdiri atas aquabidestilata dan reagen Folin-Ciocalteu. Asam galat digunakan untuk membuat kurva kalibrasi standar.

e. Penentuan Kandungan Flavonoid Total

Kandungan flavonoid total ditentukan secara spektrofotometri sesuai dengan yang dilaporkan oleh Zou dkk. (2004). Sejumlah tertentu sampel dimasukkan ke dalam labu takar $10 \mathrm{ml}$, ditambah $4 \mathrm{ml}$ aquades dan $0,3 \mathrm{~mL}$ larutan $\mathrm{NaNO}_{2} 10 \%$, dan dibiarkan selama 6 menit. Setelah itu larutan ditambah dengan 0,3 $\mathrm{mL} \mathrm{AlCl}_{3} \quad 10 \%$ dan dibiarkan selama 5 menit. Selanjutnya larutan ditambah dengan $4 \mathrm{~mL}$ $\mathrm{NaOH} 10 \%$ dan akuades sampai 10,0 mL. Larutan dibiarkan selama 15 menit dan selanjutnya dibaca absorbansinya pada panjang gelombang $495 \mathrm{~nm}$ terhadap blangko. Kuersetin digunakan untuk membuat kurva kalibrasi standar.

\section{Analisis dan Pengolahan Data}

Data yang diperoleh diolah menggunakan Microsoft Excel. Uji aktivitas penangkapan radikal DPPH dan ABTS dilakukan analisis menggunakan persamaan regresi linier untuk memperoleh nilai $\mathrm{IC}_{50}$. Aktivitas mereduksi 
ditentukan sebagai ekivalen asam askorbat (mmol asam askorbat/g fraksi). Kandungan fenolik total dinyatakan sebagai gram ekivalen asam galat tiap $100 \mathrm{~g}$ berat kering (g EAG/100 g). Kandungan flavonoid total dinyatakan sebagai gram ekivalen kuersetin tiap 100 gram berat kering ekstrak. Untuk karakterisasi gugus fungsi digunakan data spektrum IR berdasarkan daerah serapan tiap puncak yang teramati.

\section{HASIL DAN PEMBAHASAN}

\section{Nanopartikel ekstrak etanol kayu manis}

Pada proses pembuatan nanopartikel ekstrak etanol kayu manis terjadi interaksi antara muatan positif gugus amina kitosan yang terprotonasi dalam suasana asam dengan atom yang bermuatan parsial negatif dari senyawa yang terkandung dalam nanopartikel ekstrak etanol kayu manis. Dalam hal ini, muatan parsial negatif dari ekstrak etanol kayu manis dapat berasal dari gugus hidroksil senyawa fenolik dan flavonoid yang dimilikinya sehingga membentuk interaksi kitosan- $\mathrm{NH}_{3}{ }^{+}{ }^{-} \mathrm{O}-$ fenolik/flavonoid. Interaksi ionik tersebut menghasilkan ukuran nanopartikel sehingga Teknik ini disebut Teknik gelasi ionik. Selain berinteraksi dengan gugus yang bermuatan parsial negatif dari ekstrak etanol kayu manis, gugus amina kitosan yang terprotonasi membuat kitosan dapat berinteraksi dengan muatan negatif senyawa lain (Taurina dkk., 2013). Penambahan TPP bertujuan menstabilkan nanopartikel yang terbentuk melalui interaksi antara muatan positif kitosan yang ada dipermukaan kompleks kitosan-ekstrak etanol kayu manis dengan muatan negatif dari TPP.

Penentuan karakteristik nanopartikel diperlukan untuk mendapat pengertian mekanis dari perilaku nanopartikel (Abdassah, 2015). Oleh karena itu, nanopartikel ekstrak etanol yang terbentuk dikarakterisasi berdasarkan ukuran partikel, potensial zeta, dan gugus fungsi. Ukuran partikel merupakan karakteristik paling penting dalam sistem nanopartikel karena mempengaruhi langsung keunikan sifat nanopartikel (Abdassah, 2015). Pengujian dengan PSA menunjukkan bahwa nanopartikel ekstrak etanol kayu manis memiliki ukuran $400,3 \mathrm{~nm}$ seperti terlihat pada Gambar 1. Ukuran dari nanopartikel ditentukan oleh rasio antara ektrak:kitosan:STPP (Choiri $d k k$ 2016). Peningkatan konsentrasi STPP dapat mengakibatkan peninggkatan ukuran nanopartikel. Hal ini dikarenakan tingginya konsentrasi STPP berakibat pada peningkatan ketersediaan gugus $-\mathrm{NH}_{3}{ }^{+}$untuk menggabungkan partikel-partikel kecil menjadi partikel yang lebih besar (Shah $d k k$ 2016). Ukuran partikel dalam bentuk nanopartikel menentukan mudahnya partikel tersebut masuk ke dalam sel. Semakin kecil ukuran partikelnya maka akan semakin mudah masuk ke dalam sel dan semakin meningkat absorbsinya di dalam tubuh. Selain metode pembuatan, ukuran partikel nanopartikel dipengaruhi oleh perbandingan jumlah kitosan dan TPP yang digunakan, perbandingan jumlah kitosan dan obat yang ter entrap di dalamnya, dan $\mathrm{pH}$ kitosan (Taurina dkk 2013).

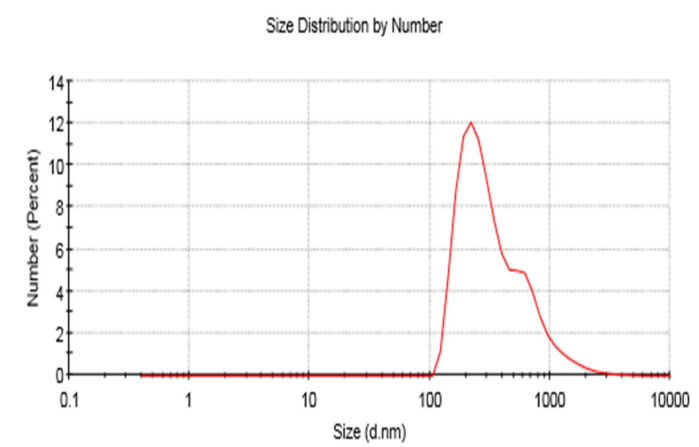

Gambar 1. Ukuran partikel nanopartikel ekstrak etanol kayu manis

Potensial zeta digunakan untuk mengkarakterisasi sifat muatan permukaan nanopartikel, berkaitan dengan interaksi elektrostatik nanopartikel (Abdassah, 2015). Dalam proses pembuatan nanopartikel, kebanyakan gugus amina dari kitosan berikatan dengan ekstrak etanol kayu manis dan TPP. Namun, kitosan merupakan polimer, gugus amina yang dimilikinya tetap tersisa dan menyebabkan densitas muatan positif yang merupakan ciri khas nanopartikel kitosan:TPP (Tripathy $d k k 2012$ dan Adhyatmika $d k k$., 2017).

Berdasarkan Gambar 2, hasil analisis potensial zeta nanopartikel ekstrak kayu manis memiliki muatan $+6,60 \mathrm{mV}$. Muatan ini jauh lebih kecil dari $+30 \mathrm{mV}$ yang menyebabkan sistem nanopartikel kurang stabil (Couvreur $d k k$., 2002), sehingga memungkinkan terjadinya agregasi antar partikel, yang mana interaksi elektrostatik akan menentukan kecenderungan agregasi dan tolak menolak. Namun perlu diingat pula bahwa semakin besar muatan nanopartikel akan bersifat toksik terhadap sel karena akan merusak membran sel. Nanopartikel sebaiknya mempunyai muatan yang cukup untuk 
menjamin stabilitasnya namun tidak toksik terhadap sel (Taurina dkk., 2013).

Beberapa penelitian menunjukkan bahwa nilai potensial zeta nanopartikel berada dibawah $+30 \mathrm{mV}$ tetapi masih memberikan nilai aktivitas biologis yang baik (Choiri dkk., 2016 dan Adhyatmika dkk., 2017). Mekanisme kerja dari nanopartikel ekstrak etanol kayu manis yang bermuatan positif yaitu melekat pada lapisan mukosa dan membrane sel yang bersifat negatif. Oleh karena itu, pembuatan nanopartikel dengan metode gelasi ionik menggunakan kitosan banyak dikembangkan sebagai cell-targeted delivery system (Luo dkk., 2010). Zeta Potential Distribution

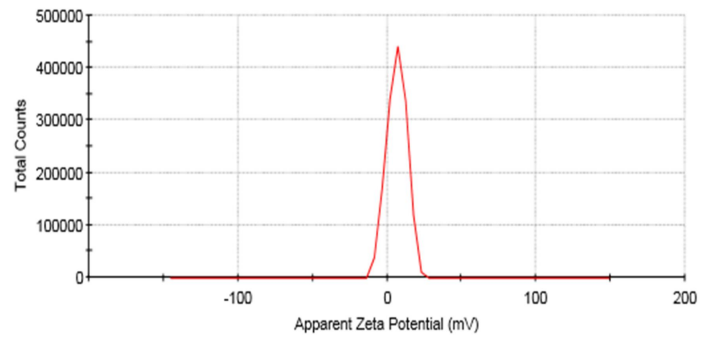

Gambar 2. Potensial zeta nanopartikel ekstrak etanol kayu manis

Karakterisasi FTIR dilakukan untuk menentukan gugus fungsi pada kitosan dan ekstrak etanol kayu manis serta STPP dalam pembuatan nanopartikel kitosan-ekstrak etanol kayu manis. Interaksi akibat ikatan silang yang terbentuk antara ekstrak etanol kayu maniskitosan-STPP dapat dilihat melalui pergeseran bilangan gelombang dan intensitas dari setiap gugus fungsi.

Putri dkk.,. (2018) melaporkan bahwa terdapat gugus $\mathrm{O}-\mathrm{H}$ pada panjang gelombang $3425,56 \mathrm{~cm}^{-1}$ pada spektra sampel kitosan murni. Hal ini menunjukkan bahwa telah terjadi interaksi antara sampel ekstrak etanol kayu manis dengan kitosan, yang ditandai dengan bergesernya bilangan gelombang gugus $\mathrm{O}-\mathrm{H}$ dari sampel nanopartikel ekstrak etanol kayu manis seperti yang terlihat pada Gambar 4. Bilangan gelombang pada gugus $\mathrm{O}-\mathrm{H}$ bergeser menjadi $3444,51 \mathrm{~cm}^{-1}$ dengan intensitas yang lebih tinggi dibandingkan dengan gugus $\mathrm{O}-\mathrm{H}$ pada spektra ekstrak etanol kayu manis pada Gambar 3. Selain gugus O-H, kitosan juga memiliki gugus fungsi $\mathrm{N}-\mathrm{H}$ yang terlihat pada bilangan gelombang $3421,57 \mathrm{~cm}^{-1}$ yang menunjukkan amida sekunder N-H ulur.

Pada spektra FTIR ekstrak etanol kayu manis (Gambar 3) bilangan gelombang tersebut tidak tampak karena belum terbentuknya ikatan antara ekstrak etanol kayu manis dan kitosan. Ikatan silang yang terjadi pada kitosan-ekstrak etanol kayu manis melibatkan STPP untuk menstabilkan nanopartikel yang terbentuk. Oleh karena itu, pada Gambar 4 terdapat serapan pada bilangan gelombang 929,10 $\mathrm{cm}^{-1}$ yang menunjukkan gugus alifatik P-O ulur dari STPP sedangkan pada Gambar 3 tidak menunjukkan serapan pada bilangan gelombang tersebut.

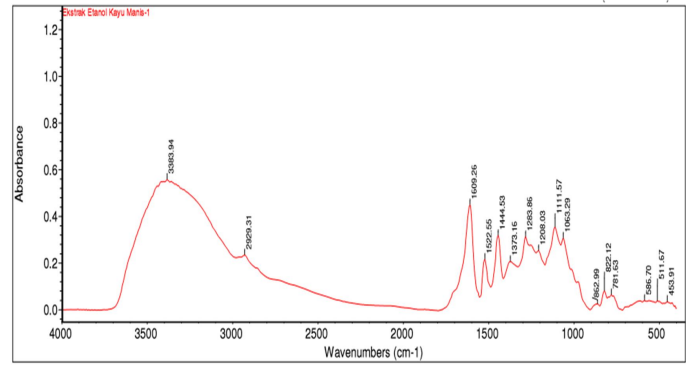

Gambar 3. Spektra FTIR ekstrak etanol kayu manis

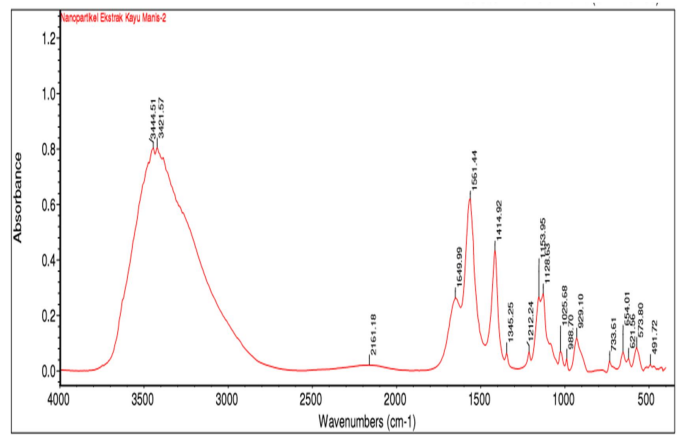

Gambar 4. Spektra FTIR nanopartikel ekstrak etanol kayu manis

\section{Aktivitas antioksidan nanopartikel ekstrak etanol kayu manis}

Aktivitas antioksidan secara in vitro dapat ditentukan melalui beberapa metode dengan mekanisme reaksi yang berbeda. Sebagaimana yang telah dilaporkan oleh Antasionasti dkk. (2017), pengujian aktivitas antioksidan dapat menggunakan metode DPPH, ABTS, dan reduksi besi III.

Pengujian aktivitas antioksidan dengan metode DPPH didasarkan pada reduksi warna ungu larutan DPPH (Floegel dkk., 2011), yang mana terjadi reaksi transfer atom hidrogen antara antioksidan dan radikal peroksil (Wootton-Beard dkk., 2011) pada panjang gelombang $517 \mathrm{~nm}$ yang mengakibatkan penurunan absorbansi. Dari hasil perhitungan Tabel 1, aktivitas antioksidan nanopartikel ekstrak etanol kayu manis tergolong dalam aktivitas sangat kuat. Hal yang sama berlaku untuk bentuk ekstraknya walaupun memiliki 
nilai $\mathrm{IC}_{50}$ lebih kecil. Hal ini menunjukkan bahwa penerapan teknologi nanopartikel pada ekstrak etanol kayu manis melalui ikat silang antara kitosan-TPP dapat mempertahankan aktivitas antioksidannya melalui mekanisme penangkapan radikal bebas DPPH.

Tabel 1. Aktivitas antioksidan nanopartikel ekstrak etanol kayu manis

\begin{tabular}{|c|c|c|c|}
\hline \multirow[b]{2}{*}{ Sampel } & \multicolumn{3}{|c|}{ Uji Aktivitas Antioksidan } \\
\hline & $\begin{array}{c}\text { DPPH- } \\
\mathrm{IC}_{50} \pm \mathrm{SD} \\
(\boldsymbol{\mu} \mathrm{g} / \mathrm{ml})\end{array}$ & $\begin{array}{c}\text { ABTS- } \\
\mathrm{IC}_{50} \pm \mathrm{SD} \\
(\boldsymbol{\mu} \mathrm{g} / \mathrm{ml})\end{array}$ & $\begin{array}{c}\text { Daya } \\
\text { Reduksi } \pm \\
\text { SD } \\
\text { (mg asam } \\
\text { askorbat } / \mathrm{g} \\
\text { ekstrak) }\end{array}$ \\
\hline $\begin{array}{c}\text { Nanopartikel } \\
\text { ekstrak } \\
\text { etanol kayu } \\
\text { manis }\end{array}$ & $\begin{array}{c}2,301 \pm \\
0,030\end{array}$ & $\begin{array}{c}2,836 \pm \\
0,023\end{array}$ & $\begin{array}{l}948,1884 \\
\pm 16,933\end{array}$ \\
\hline $\begin{array}{c}\text { Ekstrak } \\
\text { etanol kayu } \\
\text { manis }^{\mathrm{a}}\end{array}$ & $\begin{array}{c}1,939 \pm \\
0,055^{\mathrm{a}}\end{array}$ & $\begin{array}{c}2,235 \pm \\
0,014^{\mathrm{a}}\end{array}$ & $\begin{array}{l}1415,705 \\
\pm 38,609^{\mathrm{a}}\end{array}$ \\
\hline Vitamin C & $\begin{array}{c}0,554 \pm \\
0,003\end{array}$ & $\begin{array}{c}0,813 \pm \\
0,028 \\
\end{array}$ & - \\
\hline
\end{tabular}

adilaporkan oleh Antasionasti \& Jayanto (2020)

Salah satu metode penentuan aktivitas antioksidan terjadi melalui mekanisme reaksi donor hidrogen dan pemutusan ikatan pada radikal bebas $\mathrm{ABTS}^{+}$(Aktumsek dkk.,2013). Aktivitas antioksidan nanopartikel ekstrak etanol kayu manis diperlihatkan pada Tabel 1, yang mana aktivitas antioksidan yang diberikan sangat kuat. Hal yang sama berlaku untuk bentuk ekstraknya walaupun memiliki nilai $\mathrm{IC}_{50}$ lebih kecil. Hal ini menunjukkan bahwa penerapan teknologi nanopartikel pada ekstrak etanol kayu manis melalui ikat silang antara kitosan-TPP dapat mempertahankan aktivitas antioksidannya melalui mekanisme penangkapan radikal bebas ABTS. Antioksidan menekan pembentukan warna karena terjadi reduksi $\mathrm{ABTS}^{+}$sehingga terjadi penurunan absorbansi.

Pengujian aktivitas antioksidan tidak selamanya melibatkan radikal bebas tetapi dapat melalui mekanisme pengurangan ion feri $\left(\mathrm{Fe}^{3+}\right)$ dari kalium ferrisianida menjadi ion fero $\left(\mathrm{Fe}^{2+}\right)$ (Floegel dkk., 2011). Kemampuan mereduksi senyawa bioaktif tersebut dapat diasosiasikan dengan aktivitas antioksidan (Momuat \& Suryanto, 2016). Kekuatan daya reduksi sampel ditentukan berdasarkan donasi elektron dalam reduksi ferri sianida $\left[\mathrm{Fe}(\mathrm{CN})_{6}\right]^{3-}$ menjadi ferro sianida $\left[\mathrm{Fe}(\mathrm{CN})_{6}\right]^{4-}$. Kompleks $\mathrm{Fe}^{3+}$ yang tidak berwarna direduksi menjadi kompleks $\mathrm{Fe}^{2+}$ biru dengan antioksidan (Erel, 2004 dan Biskup dkk., 2013). Ion $\mathrm{Fe}^{2+}$ dapat dimonitor dengan pengukuran warna Pers's Prussian Blue pada panjang gelombang $700 \mathrm{~nm}$.

Berdasarkan data perhitungan pada Tabel 1, ekstrak etanol kayu manis $(1415,705 \pm 38,609$ mg asam askorbat/g sampel) mempunyai daya reduski besi (III) lebih besar dibandingkan dalam bentuk nanopartikelnya $(948,1884 \pm$ $16,933 \mathrm{mg}$ asam askorbat/g sampel). Namun, tetap memperlihatkan bahwa penerapan teknologi nanopartikel pada ekstrak etanol kayu manis melalui ikat silang antara kitosan-TPP dapat mempertahankan aktivitas antioksidannya melalui mekanisme donor elektron. Besarnya daya reduksi suatu ekstrak antioksidan menunjukkan kemampuannya sebagai donor elektron dan dapat bereaksi dengan radikal bebas untuk mengubahnya menjadi stabil serta mengakhiri reaksi rantai radikal.

\section{Kandungan total fenolik dan total flavonoid nanopartikel ekstrak etanol kayu manis}

Aktivitas antioksidan nanopartikel ekstrak etanol kayu manis dapat dipengaruhi oleh kandungan senyawa fenolik (Kallei dkk., 2019) melalui mekanisme reaksi netralisasi radikal bebas lipid dan mencegah penguraian hidroperoksida menjadi radikal bebas (Rohman dkk., 2010 dan Arina \& Rohman, 2013). Kandungan total fenolik dalam penelitian ini ditentukan dengan metode Folin Ciocalteau, yang mana prinsip kerja metode ini adalah dengan melihat kemampuan senyawa fenolik bereaksi dengan reagen FC (mengandung asam fosfomolibdat dan fostotuungstat), sehingga dihasilkan senyawa kompleks molibdenumtungstat biru. Untuk menentukan kandungan fenolik total diperlukan senyawa fenolik standar yaitu asam galat. Asam galat digunakan sebagai larutan standar dikarenakan asam galat mempunyai gugus hidroksil dan ikatan rangkap terkonjugasi pada masing-masing cincin benzena sehingga sangat efektif untuk membentuk senyawa kompleks dengan reagen Folin-Ciocalteu. Oleh karen itu, kandungan fenolik total dinyatakan dalam ekivalen asam galat (EAG).

Berdasarkan Tabel 2, kandungan total fenolik enanopartikel ekstrak etanol kayu manis $(61,845 \pm 0,529 \%$ EAG) lebih rendah dibandingkan dengan ekstrak etanol kayu manis $(75,685 \pm 1,408 \%$ EAG). Hal ini menunjukkan 
bahwa ada kandungan senyawa fenol yang tidak terjerap dalam proses enkapsulasi diduga karena terjadi kerusakan pada saat enkapsulasi, terutama karena oksidasi panas, oksigen, dan mekanis (Purbowati dkk., 2016). Namun, persentase senyawa fenolik yang tidak terjerap cukup rendah yaitu $18,286 \%$. Hal ini dapat dipengaruhi oleh penggunaan rpm yang tinggi $(1.500 \mathrm{rpm})$ pada saat nanoenkapsulasi, sehingga aktivitas antioksidan yang diberikan sama baiknya dengan sebelum dinanoenkapsulasi (Purbowati dkk.,., 2016). Kandungan fenolik total berkontribusi dalam aktivitas antioksidan ekstrak etanol kayu manis dan nanopartikel ekstrak etanol kayu manis, sehingga dapat dilihat bahwa aktivitas antioksidan menurun seiring dengan berkurangnya kandungan total fenolik yang terjerap dalam proses enkapsulan. Namun, aktivitas antioksidan yang ditunjukkan masih dalam kategori sangat kuat.

Tabel 2. Kandungan total fenolik total dan total

flavonoid nanopartikel ekstrak etanol kayu manis

\begin{tabular}{|c|c|c|}
\hline Sampel & $\begin{array}{c}\text { Kandungan } \\
\text { Total Fenolik } \\
\pm \text { SD }(\% \\
\text { EAG) }\end{array}$ & $\begin{array}{c}\text { Kandungan } \\
\text { Total } \\
\text { Flavonoid } \pm \\
\text { SD }(\% \text { EK) }\end{array}$ \\
\hline $\begin{array}{c}\text { Nanopartikel } \\
\text { ekstrak etanol } \\
\text { kayu manis }\end{array}$ & $\begin{array}{c}61,845 \pm \\
0,529\end{array}$ & $\begin{array}{c}57,939 \pm \\
0,446\end{array}$ \\
\hline $\begin{array}{l}\text { Ekstrak etanol } \\
\text { kayu manis }\end{array}$ & $\begin{array}{c}75,685 \pm \\
1,408^{\mathrm{a}}\end{array}$ & $\begin{array}{c}60,546 \pm \\
0,670^{\mathrm{a}}\end{array}$ \\
\hline
\end{tabular}

adilaporkan oleh Antasionasti \& Jayanto (2020)

Flavonoid adalah kelompok senyawa fenolik tumbuhan yang paling umum dan tersebar luas, dicirikan oleh struktur benzo- $\gamma$ piron (Arina \& Rohman, 2013). Penentuan kandungan total flavonoid mengikuti metode yang dilakukan oleh Zou dkk. (2004) dengan menggunakan spektrofotometri yang didasarkan pada pembentukan kompleks dengan logam $\mathrm{Al}$ menghasilkan warna kuning yang selanjutnya bereaksi dengan $\mathrm{NaOH}$ menjadi merah muda yang meningkat intensitasnya. Dalam pengujian digunakan kuersetin sebagai standar sehingga kandungan total flavonoid dinyatakan dalam ekivalen kuersetin (EK).

Berdasarkan Tabel 2, kandungan total flavonoid nanopartikel ekstrak kayu manis $(57,939 \pm 0,446 \%$ EK) lebih rendah dibandingkan dengan ekstrak etanol kayu manis $(60,546 \pm 0,670 \%$ EK). Hal ini menunjukkan bahwa ada kandungan senyawa flavonoid yang tidak terjerap dalam proses enkapsulasi diduga karena terjadi kerusakan pada saat enkapsulasi, terutama karena oksidasi panas, oksigen, dan mekanis (Purbowati $d k k$., 2016). Kondisi ini menunjukkan bahwa sebagian senyawa fenolik yang tidak terjerap tergolong senyawa flavonoid. Persentase senyawa flavonoid yang tidak terjerap cukup rendah yaitu 4,306 \%. Hal ini dapat dipengaruhi oleh penggunaan rpm yang tinggi $(1.500 \mathrm{rpm})$ pada saat nanoenkapsulasi, sehingga aktivitas antioksidan yang diberikan sama baiknya dengan sebelum dinanoenkapsulasi (Purbowati dkk., 2016). Kandungan total flavonoid berkontribusi dalam aktivitas antioksidan ekstrak etanol kayu manis dan nanopartikel ekstrak etanol kayu manis, sehingga dapat dilihat bahwa aktivitas antioksidan menurun seiring dengan berkurangnya kandungan total flavonoid yang terjerap dalam proses enkapsulan. Namun, aktivitas antioksidan yang ditunjukkan masih dalam kategori sangat kuat.

\section{KESIMPULAN}

Nanopartikel ekstrak etanol kayu manis memiliki kemampuan antioksidan sangat kuat sehingga dapat menjadi salah satu alternatif antioksidan. Penerapan teknologi nanopartikel pada ekstrak etanol kayu manis melalui ikat silang antara kitosan-tripolifosfat dapat mempertahankan aktivitas antioksidannya.

\section{DAFTAR ISI}

Abdassah, M., 2015. Nanopartikel Dengan Gelasi Ionik. Farmaka. 15(1), 45-52.

Abdelwahab, S. I., Mariod, A. A., Taha, M. M. E., Zaman, F. Q., Abdelmageed, A. H. A., Khamis, S., Sivasothy,Y. \& Awang, K. 2017. Chemical composition and antioxidant properties of the essential oil of Cinnamomum altissimum Kosterm. (Lauraceae). Arabian Journal of Chemistry, 10(1), 131-135.

Adhyatmika, Martien, R., Rochmadi, Ismail, H., 2017. Preparasi Nanopartikel Senyawa Pentagamavunon-0 Menggunakan Matriks Polimer Kitosan Rantai Sedang dan Pengait Silang Natrium Tripolifosfat Melalui Mekanisme Gelasi Ionik Sebagai 
Kandidat Obat Antiinflamasi. Majalah Farmaseutik. 13(2), 65-78.

Aktumsek, A., Zengin, G., Guler, G.O., Cakmak, Y.S., dan Duran, A., 2013. Antioxidant potentials and anticholinesterase activities of methanolic and aqueous extracts of three endemic Centaurea L. species. Food and Chemical Toxicology. 55, 290-296.

Antasionasti, I., Riyanto, S. \& Rohman, A. 2017. Antioxidant Activities and Phenolics Contents of Avocado (Persea americana Mill.) Peel in vitro," Research Journal of Medicinal Plants. 11(2), 5561.

Antasionasti, I., \& Jayanto, I., 2020. Aktivitas Antioksidan Ekstrak Etanol Kayu Manis (Cinnamomum burmani) Secara In Vitro. Seminar Nasional dan Workshop Tumbuhan Obat Indonesia dan Pelayanan Kesehatan Tradisional. [in press].

Ariestiani, B., Purbowatingrum, Ngadiwiyana, Ismiyarto, Fachriyah, E., \& Nurani, K. 2018. Antioxidant activity from encapsulated Cinnamaldehyde-Chitosan. Journal of Physics: Conference Series. 1025, 012132.

Arina, N. B. \& Rohman, A. (2013). The phenolic contents and antiradical activity of Indonesian Phyllantus urinaria L., International Food Research Journal, 20(3), 1119-1124.

Biskup, I., Golonka, I., Gamian, A. \& Sroka, Z. (2013). Antioxidant activity of selected phenols estimated by ABTS and FRAP methods. Postepy Hig Med Dosw, 67(184), 958-963.

Choiri, Z., Ronny M., dan Nanung D., 2016. Biosintesis dan Karakterisasi NanoEnkapsulasi Ekstrak Buah Mengkudu (Morinda citrifolia) dengan KitosanSodium Tripolifosfat sebagai Kandidat Antioksidan Alami. Prosiding Simposium Nasional Penelitian dan Pengembangan Peternakan Tropik. Hal 22-28.

Chun, O.K., Kim, D.-O., dan Lee, C.Y., 2003. Superoxide radical scavenging activity of the major polyphenols in fresh plums. Journal of Agricultural and Food Chemistry. 51, 8067-8072.

Couvreur, P., Barrat, G., Fattal, E., Legrand, P., Vauthier, C., 2002, Nanocapsule Technology: a Review, Critical Review Therapeutic Drug Carrier Systems. 19, 99-134.
Erel, O. (2004). A novel automated direct measurement method for total antioxidant capacity using a new generation, more stable ABTS radical cation. Clinical Biochemistry. 37(4), 277-285.

Ervina, M., Lie, H. S., Diva, J., Caroline, Tewfik, S. \& Tewfik, I. 2019. Optimization of water extract of Cinnamomum burmannii bark to ascertain its in vitro antidiabetic and antioxidant activities. Biocataliysis and Agricultural Biotechnology. 23(3), 1346-1350.

Ervina, M., Nawu, Y. E. \& Esar, S. Y. 2016. Comparison of in vitro antioxidant activity of infusion, extract and fractions of Indonesian Cinnamon (Cinnamomum burmannii) bark. International Food Research Jornal. 23(3), 1346-1350.

Fathi, M., dan Julian, D. 2014. Nanoencapsulation of food ingredients using carbohydrate based delivery systems. Trends in Food Science \& Technology. 39, 18-39.

Floegel, A., Kim, D. O., Chung, S. I., Koo, S, I. \& Chun, O. K. (2011). Comparison of ABTS/DPPH assays to measure antioxidant capacity in popular antioxidant-rich US foods. Journal of Food Composition and Analysis. 24(7), 1043-1048.

Hinneburg, I., Damien Dorman, H.J., dan Hiltunen, R., 2006. Antioxidant activities of extracts from selected culinary herbs and spices. Food Chemistry. 97, 122-129.

Kallel, I., Hadrich, B., Gargouri, B., Chaabane, A., Lassoued, S., Gdoura, R., Bayoudh, A. \& Messaoud, E. B. 2019. Optimization of Cinnamon (Cinnamomum zeylanicum Blume) Essential Oil Extraction: Evaluation of Antioxidant and Antiproliferative Effects. Evidence-based Complementary and Alternative Medicine. 1-11.

Kikuzaki, H., Hisamoto, M., Hirose, K., Akiyama, K., dan Taniguchi, H., 2002. Antioxidant properties of ferulic acid and its related compounds. Journal of Agricultural and Food Chemistry. 50, 2161-2168.

Luo, Y., Zhang, B., Cheng, W. and Wang, Q. 2010, Preparation, Characterization and Evaluation of Selenite-Loaded Chitosan/TPP Nanoparticles with or Without Zein Coating. Carbohydrate Polymer. 82, 942-951. 
Momuat, L. I. \& Suryanto, E. (2016). Pengaruh Lama Perendaman Terhadap Aktivitas Antioksidan Dari Empelur Sagu Baruk (Arenga microcharpha). Chemistry Progress. 9(1), 21-28.

Mora-huertas, C. E., Fessi, H., dan Elaissari, A. 2010. Polymer-based nanocapsules for drug delivery. International Journal of Pharmaceutics. 385, 113-142.

Muhammad, D. R. A., Tuenter, E., Patria, G. D., Foubert, K., Pieters, L. \& Dewettinck, K. 2020) Phytochemical composition and antioxidant activity of Cinnamomum burmannii Blume extracts and their potential application in white chocolate. Food Chemistry. 340, 127983.

Munin, A., dan Edwards-lévy, F. 2011. Encapsulation of natural polyphenolic compounds; a review. Pharmaceutics. 3, 793-829.

Nawasari, I. P. S., 2018. Kajian Potensi Kayu Manis dan Teh sebagai Pangan Antidiabetes. Jurnal Kesehatan. 9(3), 485-497.

Purbowati, I. S. M., Syamsu, K., Warsiki, E., \& Sri, H., 2016. Stabilitas Senyawa Fenolik Dalam Ekstrak dan Nanokapsul Kelopak Bunga Rosella Pada Berbagai Variasi $\mathrm{pH}$, Suhu, dan Waktu. Agrointek. 10(1), 31-40.

Putri, A. I., Sundaryono, A., \& Candra, I. N., 2018. Karakterisasi Nanopartikel Kitosan Ekstrak Daun Ubijalar (Ipomoea Batatas L.) Menggunakan Metode Gelasi Ionik. Alotrop. 2(2), 203-207.

Rohman, A., Riyanto, S., Yuniarti, N., Saputra, W. R., Utami, R. \& Mulatsih, W. (2010). Antioxidant activity, total phenolic, and total flavaonoid of extracts and fractions of red fruit (Pandanus conoideus Lam). International Food Research Journal. 17(1), 97-106.

Sana, S., Arshad, S. M. U., Farhan, Ahmad, R., Ali, I. \& Tabussam, T. 2019. Nutritional characterization of cinnamon and turmeric with special reference to their antioxidant profile. International Journal of Biosciences. 15 (4), 178-187.

Saha P., Goyal AK., Rath G., 2010. Formulation and evaluation of chitosan-based ampicillin trihydrate nanoparticles. Tropical Journal of Pharmaceutical
Research. 9(5): 483-488.

Shah, B. R., Yan L., Weiping J., W., Yaping A., Lei H., Zhenshun L., Wei X., dan Bin L. 2016. Preparation and optimization of pickering emulsion stabilized by chitosantripolyphosphate nanoparticles for curcumin encapsulation. Food Hydrocolloids. 52, 369- 377.

Shahid, M. Z., Saima, H., Yasmin, A., Nadeem, M. T., Imran, M. \& Afzaal, M. 2018. Antioxidant capacity of cinnamon extract for palm oil stability. Lipids in Health and Disease. 17(1), 1-8.

Taurina, W., Martien, R., \& Ismail, H., 2013. Preparasi Nanopartikel Gamavuton-0 Menggunakan Kitosan Rantai Pendek dan Tripolifosfat Sebagai Cross Linker. Jurnal Ilmiah Farmasi. 10(2), 60-68.

Tripathy, S., Sabyasachi D., Subhankari P. C., Sumanta K. S., Panchanan P., dan Somenath R. 2012. Synthesis, characterization of chitosan tripolyphosphate conjugated chloroquine nanoparticle and its in vivo anti-malarial efficacy against rodent parasite : A dose and duration dependent approach. International Journal of Pharmaceutics. 434(1-2), 292-305.

Wijayanti, W. A., Zetra, Y. \& Burhan, P. 2006. Minyak Atsiri Dari Kulit Batang Kayu Manis (Cinnamomum burmannii) Dari Famili Lauraceae Sebagai Insektisida Alami, Antibakteri, Dan Antioksidan. Jurusan Kimia FMIPA Intitust Teknologi Sepuluh Nopember.

Wootton-Beard, P. C., Moran, A. \& Ryan, L. (2011). Stability of the total antioxidant capacity and total polyphenol content of 23 commercially available vegetable juices before and after in vitro digestion measured by FRAP, DPPH, ABTS and Folin-Ciocalteu methods. Food Research International. 44(1), 217-224.

Zou, Y., Lu, Y., dan Wei, D., 2004. Antioxidant activity of a flavonoid-rich extract of Hypericum perforatum L. in vitro. Journal of Agricultural and Food Chemistry. 52, 5032-5039. 